\title{
Creating sustainable postgraduate supervision learning environments through critical emancipatory research
}

\author{
$M M N K O A N E^{1}$
}

Abstract

This article articulates pedagogic praxis for postgraduate supervision couched within sustainable learning environments with emancipatory aims. The paper probes the discourses of hegemony as a form of power that relies on non-coercive control by supervisors over students (master-apprentice model). Furthermore, it proposes a counter-hegemonic pedagogic praxis informed by critical emancipatory research. I amplify how postgraduate supervision could be a liberating experience, drawing from my own experiences as part of a supervisory team of 15 academics and cohort of 28 doctoral and 22 master's students. The article interrogates the struggles on the continuum of power formations between supervisor and students. It proposes an alternative, liberating postgraduate supervision as a pedagogic praxis to counter the dominant discourse. It concludes by emphasising the importance of creating enabling sustainable learning environments with a promise of a counter-hegemonic praxis that requires rearranging master-apprentice relations.

Key words: sustainable learning environments, social justice, emancipation, pedagogic praxis, critical emancipatory research.

\section{Introduction}

Considerable ink has flowed on a 'hot' topic on the postgraduate research agenda in recent years and the discourses on supervision, in particular, but there have been few debates on how to create sustainable learning environments in which students might reclaim freedom in knowledge production. According to Petersen (2007), much research has explored the features of 'effective' supervision, guidelines about supervision, and supervisory arrangements and practices (see Craswell, 1996; Dinham \& Scott, 1999; Humphrey \& McCarthy, 1999; Golde, 2000; Kiley \& Mullins, 2001; de Valero, 2001; Ives \& Rowley, 2005). In this article, I wish to contribute to the debate by highlighting and condensing pedagogic praxis for supervision located within sustainable learning environments with emancipatory aims, and probing discourses or challenges of the hegemony that manifests itself in power relations between supervisor and student. Petersen (2007) further argues that postgraduate pedagogic praxis is a field that tends to be 'radically under-theorised'.

Postgraduate supervision is seen as relations between the supervisor and the supervisee and privileged discourses or knowledge economy. This relationship is about respect for the other

\footnotetext{
$1 \quad$ Molebatsi Milton Nkoane (PhD), Senior Lecturer in the Faculty of Education at the University of the Free State and Founding Member of the NRF sponsored Sustainable Learning Environments research project. Email:nkoanemm@ufs.ac.za
} 
person and ensuring that there is fairness in all interactions and sensitivity towards manifestation of power, thus meaning how the parties involved in this intellectual journey handle issues of power and generation of knowledge. Social justice becomes a norm in this kind of relationship because it is about respect and addresses issues of equity, freedom, peace and hope. Social justice in postgraduate pedagogic praxis challenges hegemony in postgraduate supervision and advocates respect that drives towards equity rather than marginalisation.

\section{Postgraduate pedagogic praxis as intersect}

In this light, I argue that the supervisor and supervisee on this intellectual journey have to negotiate the boundaries of what it means to conduct research at postgraduate level. This is where confusion and overlaps become a challenge, because the supervisor has to oversee the successful appropriation of the power relations while boundaries are reconstructed and challenged. Waghid (2006) argues that this new relationship between the supervisor and students should not be mistaken for that between a customer and a supplier. This new relationship ought to be constituted by freedom and friendship, which can hopefully take place in dialogical spaces or relationships with others through which possibilities are opened up toward what might be, should be, is not yet. The parties ought to open a platform to communicate and construct alternative possibilities to establish new relation that is neither a relation of supplier and consumer nor of master and apprentice. This should be a pedagogic relationship that transforms and empowers both parties and enhances the principles of democracy. This ought to be blended within Freire's transformative and emancipatory pedagogic praxis. Through this kind of pedagogic relationships values such a democracy, social justice, empowerment and sustainable learning environments could be realised. It is about the understanding of the world experiences of both parties involved.

I could conceptualise the supervisory relationship as one in which boundaries are negotiated. Nkoane (2009) asserts that power relations could be eliminated and changed within dialogical spaces. We can understand that power is not given, but individually and collaboratively created within the emerging praxis in which the supervisor and supervisee are engaged. Within social justice postgraduate pedagogic praxis, empowerment becomes the core justification of liberty. The supervisor does not treat the student as an object or a means towards an end. Importantly, both supervisor and supervisee have an important role to play in the construction of new forms of knowledge. If we think of dialogical spaces as a negotiated settlement that empowers both parties, then we understand that empowerment is not the gift of the powerful.

It is important to note that the postgraduate pedagogic praxis as intersect should be rooted in the enlightenment of social justice and bring about emancipation, rationality and liberation. I argue that this approach could bring empowerment and see postgraduate students as thinking, rational and complex human beings that are able to produce knowledge. We need to go beyond the limits of traditional and create sustainable learning environments for postgraduate students that would empower, enlighten and emancipate. Green (1988) argues for freedom as a form of human consciousness whereby supervisors can rouse postgraduate students 'to go in search of their own', meaning to provoke them to reach beyond themselves, to wonder, to imagine and to pose their own questions. This is empowerment, because students are able to think about what they are doing, and they are given a platform to share their meanings and to conceptualise and make sense of their world-life experiences. 
It becomes interesting to explore how students construct knowledge and draw upon resources in this intellectual journey, instead of directing them to reproduce the master's own knowledge. If we take the languages, histories, experiences and voices of the students seriously and integrate that with our knowledge, postgraduate research becomes a dynamic experience. This pedagogic praxis at postgraduate level creates possibilities for new makings of reality, and the new possibilities for being that emerge from these intersections of relationships between supervisor and supervisee.

What I find particularly interesting in this pedagogic praxis is the liberating effect on supervisors, because they move away from being technicist and assume a new role, becoming co-constructors and co-learners in the knowledge constructed by their postgraduate students. In a sustainable learning environment a supervisor is critical about how knowledge is constructed and advocates the importance of human interactions and relations, and sees students as able, speaking and interpreting beings who have to be approached differently (see Wuthnow, Hunter, Bergesen \& Kurzwell, 1985; Mahlomaholo \& Matobako, 2006; Nkoane, 2009).

\section{Counter-hegemony discourse an alternative for postgraduate supervision}

As Fairclough (2003) suggests, discourse is not only about words or texts, but rather about discursive formations and practices that exist and operate among social practices. Discourse as practice systematically forms the objects that are spoken of. Discourses are made of words or signs, but they involve more than just the use of those signs to refer to pre-existing praxis (Hongwane, 2009). An interesting aspect, which seems to feature power relations and dominance is how discursive praxis is produced through and reflected in language and in practices. Postgraduate supervision has residuals of the dominant discourses prevalent in society. Discourses are both informative and instructive; that is, they tell us how the world is arranged and how we should interact with the social order.

Humankind has gone through many struggles against imperialism, ranging from colonisation, marginalisation, superiority, claims of being custodians or bearers of knowledge, and expertise in a discipline area or knowledge that is fluid and dynamic in nature. All these discourses and claims might be leaving the arenas of academia through the front door and reentering from through the back door, unless we start changing our own pedagogic praxis.

Postgraduate students might be unable to articulate or construct their knowledge, to unite their life experiences and those of their societies without resorting to the 'master' with a 'super-vision'. This kind of practice creates cycles of reproduction of knowledge from the know-all expert or 'master'. In this article I am referring to this pedagogic praxis as a hegemonic intellectual order that protects the master's intellectual tradition of how knowledge is constructed. Antonio Gramsci (1971) asserts that hegemony is non-coercive control, but that it does not rule out the possibility of using force.

A sustainable learning environment adopts a revolutionary intellectual stance that could reveal the weakness of the existing postgraduate pedagogic praxis to advance an alternative intellectual praxis. I propose a counter-discourse, located within critical theory and informed by sustainable learning environments and critical emancipatory research practice. This intellectual revolution is a counter-hegemonic pedagogic praxis that requires re-arranging or deconstructing power-relationships between 'master and apprentice' (i.e. supervisor and 
student) and changing the state of mind between the two. Postgraduate supervision should be seen as creating enabling, sustainable learning environments to support students.

According to Nulty, Kiley and Meyers (2009), supervisors or promoters are expected to coach and mentor, teach, guide and advise students. Waghid (2006) offers a counter-discourse by asserting that there should be a higher level of freedom and friendship for postgraduate students' supervision in order to cultivate a culture of 'authentic' learning different from one that advocates a consumer market-driven 'logic'. This kind of supervisory pedagogic praxis offers a particular conceptualisation which counter-hegemony with broad lens through which postgraduate supervision could be transformed. This conceptualisation has a social justice agenda as its central focus and the intent of challenging or disrupting inequities in the traditional postgraduate supervision praxis where necessary. It is informed by the discourse that knowledge is socially constructed and dynamic, thus indicating that the notion of an expert holds no water. This praxis challenges the silencing of postgraduate students' voices and interrogates the notion of 'whose knowledge is it anyway?'

To use Foucault's theoretical lens on social justice education and critical emancipatory research is to challenge the power wielded by the strong over the weak. He maintains that to remain committed to the struggle of those on the periphery, you need to engage in the 'games of truth' on societal and educational hegemony by challenging power relations that subjugate people, and by maintaining democracy, freedom, peace and hope. I regard Foucault's discourse as relevant in postgraduate pedagogic praxis, where both the supervisor and supervisee need to challenge hegemony. Countering dominant discourses by levelling the playing fields for those assumed to be without power, voices, skills, and knowledge (in these instance postgraduate students) must be able to take centre-stage. In this light, I argue that dominant discourse and power is not a property of powerful supervisors as discursive formations and practices have purported them to be (see Foucault, 1997; Nkoane, 2012).

\section{Struggles on the continuum of power formations}

I am part of a team of 15 academics drawn from a wide range of academic disciplines within the Faculty of Education at the University of the Free State. We are supervising a cohort of 28 doctoral and 22 master's students using critical emancipatory research as a theoretical framework for addressing diverse research problems. The use of a cohort enables group work and sharing ideas and literature sources. It is built into the workshops that are continued throughout the period of research. We encourage groups to form working cells and critical reader groups to provide support during the intellectual journey; this seems to reduce isolation and builds a community of practice. The cohort provides motivation for supervisors and students alike, as they share progress and provide critique of each other.

This eclectic supervisory team helps us to navigate the intellectual journey, moving from one theoretical or conceptual stance to another with ease. What makes us humble is the intersections between us as supervisors and our students; perhaps our varied or subjective interpretations of realities become important to consider and negotiate in the process. The steel rod that holds us together is critical emancipatory research, which requires us (in this instance students and supervisor) to become totally immersed as equal partners in this intellectual journey. Through this approach of informed eclecticism we value principles of democracy, social justice, sustained livelihood and empowerment of all. In this light, I argue that student and supervisory relations are harnessed, and students' varied or subjective interpretations and understanding of realities are respected and acknowledged in the process 
of knowledge construction. Supervision in this fashion is sensitive to the plight of students, is democratic, is open to a myriad of contradictions and respects students as knowing people who assume the identity of students. We are conscious that student formations are informed by people of different genders, classes, ages, ethnic groups, religions and sexual orientations, who enact the role of a student. Consequently we have to respect them as equals. We have to be empathetic, courageous, and compassionate in making meaning of their research work and seeing the world through their eyes (see Mahlomaholo \& Nkoane, 2002; Nkoane 2012).

Waghid's conceptualisation of how as supervisors we could navigate struggles on the continuum of power formations and harness friendship in order to achieve 'authentic' learning is a powerful example. He writes:

If I supervise students, then I must first declare myself a 'friend-who-loves', since I
would not be loved in return ... loving relationship is an attitude, an orientation of
character which determines the relatedness of a person to other in the context in which
they find themselves... loving relationships are 'brotherly'/ sisterly' because they invoke
a sense of responsibility, care and respect towards others ... as a supervisor I should
create conditions whereby students learn ... to be caring towards students;
democratizing interactions ... students take the initiatives to imagine the possibilities
and to be respectful towards students (Waghid, 2006: 434).

The power of his conceptualisation of caring and love is revealed when one locates it within the ambit of sustainable learning environments and social justice. For instance, a sustainable learning environment is socially just and empowering when supervisors are caring, loving and showing respect. This gives both the supervisor and students power to perform and cognitively navigate their way in this intellectual journey of constructing and producing knowledge.

The point about the notion of power formations between supervisor and students is that the traditional supervisory pedagogy has bestowed on the supervisor the role of a knowing authority, who is in a position of power and has the task of overseeing the students' work. This creates tensions because students are perceived as tabulae rasae or clean slates, as individuals who cannot make meaning of their histories and/or lifeworld experiences. We can certainly understand the persona that is unconsciously or consciously engraved on the minds of supervisors to qualify in differentially constructed power formations and elevate them to the status of a 'superman or superwoman in a telephone booth'. This kind of hegemony is bestowed in the minds of supervisors or promoters by the university or faculty, denoting: experience, successful researcher, expert in knowledge area, overseer of student, source of knowledge and examiner (see Boud \& Lee, 2005; Johnson, Lee \& Green, 2000; Petersen, 2007).

In this light, I see a hegemonic relation between supervisor and students, because students are marginalised, relegated and pushed to the periphery as not knowing, inexperienced and products of a supervisor, what Waghid (2006) refers to as relationship of customer and supplier. In these struggles of power formations the central question is: whose knowledge is constructed, that of supervisor or students? Grant points out (2005) that students' knowledge is usually examined according to criteria that are often not clear to the student. What I find particularly interesting and disturbing in the struggles of power formations is: Whose voice should be heard? 


\section{A promise to counter-hegemonic pedagogic praxis}

In this paper, I have offered a particular conceptualisation of pedagogic praxis for postgraduate supervision, understanding it from Foucault's theory of archaeology and genealogy. This means studying power and knowledge in the context of the supervision process. Foucault (1977) states clearly that individuals should resist power or dominance exercise over them. The two theoretical stances of archaeology and genealogy may prove useful for reflection on the dominant discourse relegating postgraduate students, and on counter-hegemonic discourses and promises of emancipation, liberation, empowerment, democracy, equity, hope, peace, social justice and the grwoing chorus of voices of postgraduate students demanding to be heard, respected and acknowledged (Nkoane, 2010).

It is important to undertake to counter hegemonic discourse, as it will allow us to reflect on discourse that contests silencing the voices and bodies of knowledge and experience that postgraduate students possess. This represents the critique of our own postgraduate supervision or pedagogic praxis at universities and critique on the persona bestowed upon us, and draws our attention to being sensitive, human and respectful, and working towards creating sustainable learning environments that are socially and academically just. Mahlomaholo (1998) states clearly that the dominant discourses 'seldom reign without some challenge from the dominated'.

What is interesting about the promise to counter the dominant discourses discussed above is the way it is informed by theoretical positions that strive for emancipation and social justice. The discourses clearly demystify labelling theories that are created and sometimes packaged in a covert manner (in this instance students who know less). In the history of humankind, markers and labels were created by misogyny to relegate, marginalise and downgrade women. In this article, I offered a particular theoretical lens to rethink and look again at postgraduate supervision and understand it as opposing the dominant discourse that sees postgraduate student as 'customers' and supervisors as 'suppliers'. Seeing students as different from supervisors disempowers students, because it relegates and marginalises them to a particular social station, where they are described as less rigorous, incompetent and less assertive. In essence, this is what this article has to offer: a particular conceptualisation of how we could understand postgraduate supervision so that students may be empowered (see Foucault, 1977; Duncan, 1993; Glough, 1998; Mahlomaholo, 1998; Nkoane, 2010).

\section{Conclusion}

In this article, I have attempted to demonstrate how privileged or dominant discourses can advance power by elevating supervisors or 'masters' to the position of 'superiority' and downgrade or marginalise students or 'apprentices' to an inferior social station. Interrogating and probing discursive formations and practices that exist in postgraduate supervision will be liberating not only for students, but for the supervisor as well. I took a stance to diffuse the notion of the power of the 'master' in this article, because it would imply that the supervisor is a master of knowledge. This is a problematic view, because knowledge is dynamic and fluid as it has no distinctive boundaries. Herein lies the difficulty of any supervisor or 'master' who claims to be a knowledge expert. The question at the heart of the 'master and apprentice' model is, who is the holder of power and authority? The implication is that the master is more powerful and knowledgeable than the other. In our cohort team, we have noticed how important it is to create a sustainable learning environment that is empowering and upholds the values of democracy and social justice. However, we are conscious that this postgraduate 
pedagogic praxis is not natural; it is an artifice that must always be negotiated, elaborated and adjusted anew.

\section{References}

Boud, D. \& Lee, A. 2005. Peer learning as pedagogic discourse for research education. Journal of Studies in Higher Education, 30(5): 501-515.

Craswell, G. 1996. This unfathomable thing called supervision: negotiating better working relationships with supervisors, in Quality postgraduate research: is it happening? Conference proceedings 18-19 April 1996 - Quality in Postgraduate Research. Adelaide.

de Valero, Y.F. 2001. Department factors affecting time-to-degree and completion rates of doctoral students at one land-grant research institution. Journal of Higher Education. 72(3): 341-367.

Dinham, S. \& Scott, C. 1999. The doctorate: talking about the degree. Nepean: University of Western Sydney.

Duncan, N.T.F. 1993. Discourse and racism. Unpublished Ph.D. thesis. South Africa: University of Western Cape.

Fairclough, N. 2003. Analysis of discourse: Textual analysis for social research. New York: Routledge.

Foucault, M. 1977. Discipline and punish: The birth of the prison. Harmondsworth: Penguin.

Foucault, M. 1997. The ethics of the concern for self as practice of freedom. In P. Rabinow (Ed.), Michel Foucault: Ethics: Subjectivity and Truth, vol. 1. New York: The New Press.

Gramsci, A. 1971. Prison Notebooks. London: International Publishers Company.

Grant, B. 2005. Fighting for space in supervision: Fantasies, fairytales, fictions and fallacies. International Journal of Qualitative Studies in Education 18(3): 337-354.

Glough, D. 1998. Managing inclusive education: From policy to experience. London: Paul Chapman Publishing.

Golde, C.M. 2000. Should I stay or should I go: student descriptions of the doctoral attrition process, Review of Higher Education. 23(2): 199-227.

Green, M. 1988. The dialectic of freedom. New York: Teachers College Press.

Hongwane, V. 2009. Educational Research and Transformation in South Africa. In H. Piper, J.Piper, \& S.Mahlomaholo, S. (Eds.), deconstructing higher education transformation as trauma through narratives, (pp. 31--40). Science Africa, South Africa: Platinum Press.

Humphrey, R. \& McCarthy, P. 1999. Recognising difference: providing for postgraduate students. Journal of Studies in Higher Education. 24(3): 371-386.

Ives, G. \& Rowley, G. 2005. Supervisor selection or allocation and continuity of supervision: Ph.D. students' progress ad outcomes. Journal of Studies in Higher Education. 30(5): 535-555. 
Johnson, L., Lee, A. \& Green, B. 2000. The Ph.D. and the autonomous self: gender, rationality and postgraduate pedagogy, Journal of Studies in Higher Education. 25(2) 135-147.

Kiley, M. \& Mullins, G. 2001. Evaluation of postgraduate research experience: a proposed model for Adelaide University. In Student feedback on teaching: reflections and projection. Refereed Conference Proceedings - Teaching Evaluation Forums 28-29 August: 60-69.

Mahlomaholo, M.G. 1998. Signification of African cultural identity, individual African identity and performance in mathematics among some Grade 9 African Pupils in Mangaung High Schools. Unpublished Ph.D. Thesis. South Africa: University of Western Cape.

Mahlomaholo, M.G. \& Matobako, S.T.P. 2006. Service Learning in South Africa held terminally captive by legacies of the past. Journal of Centre for Study of Southern African Literature and Languages (Alternation). 13 (1): 2003-217

Mahlomaholo, M.G. \& Nkoane, M.M. 2002. The case of emancipatory qualitative research: Reflection on assessment of quality. Journal of Education as Change/Onderwys as Verandering. 6(1): 89-105. Faculty of Education and Nursing - RAU.

Nkoane, M.M. 2009. Educational Research and Transformation in South Africa. In H. Piper, J.Piper \& S. Mahlomaholo (Eds.), Critical and radical learning discourse: Towards a pedagogy for empowerment (pp. 21-30). South Africa: Platinum Press.

Nkoane, M.M. 2010. Listening to the voices of the voiceless: A critical consciousness for academic industrial complex. South African Journal of Higher Education. 24(3) 317341.

Nkoane, M.M. 2012. Critical emancipatory research for social justice and democratic citizenship. Journal of Perspectives in Education. 30(4) 98-104.

Nulty, D., Kiley, M., \& Meyers, N. 2009. Promoting and recognising excellence in the supervision of research students: An evidence-based framework. Journal of Assessment and Evaluation in Higher Education. 34(6): 1-15.

Petersen, E.B. 2007. Negotiating academicity: postgraduate research supervision as a category boundary work. Journal of Studies in Higher Education. 32(4): 475-487.

Waghid, Y. 2006. Reclaiming freedom and friendship through postgraduate student supervision. Journal of Teaching in Higher Education. 11(4): 427-439.

Wuthnow, R., Hunter, J.D., Bergesen, A., \& Kurzwell, E. 1985. Cultural Analysis The works of Perter L Berger, MARY Douglas, Michel Foucault and Jurgen Habermas. London: Routledge and Kegan Paul. 